\title{
Assessment of seed quality and sex determination in hop seedlings using molecular markers
}

\author{
Avaliação da qualidade de sementes e determinação de sexo em mudas \\ de lúpulo utilizando marcadores moleculares
}

\begin{abstract}
Marília Pereira Machado', Andreza Cerioni Belniaki", André Felipe Bernert "II, Erik Nunes Gomes' ${ }^{\mathrm{IV}}$, João Carlos Bespalhok Filhov, Maristela Panobiancovi, Cícero Deschamps ${ }^{\mathrm{VII}}$
\end{abstract}

\begin{abstract}
Brazil is the world's third largest beer consumer and currently imports all of its hops for the brewing industry. Such a fact justifies the selection of hop genotypes adapted for cultivation locally, which requires high quality seeds and efficient sex determination of the seedlings. The objectives of this study were to develop a methodology to assess hop seed quality and to efficiently determine hop seedling sex through the use of male-specific molecular markers. Freshly harvested hop seeds were germinated with and without pre-chilling $\left(3-5^{\circ} \mathrm{C}\right)$ for 3,6 and 12 weeks and then germinated at 20 or $25^{\circ} \mathrm{C}$ in the presence or absence of light, evaluating germination percentage and germination speed index. F1 progenies were obtained from after seed germination in a greenhouse and seedlings sex was determined using male-specific molecular markers. The best conditions for physiological quality assessment of hop seeds used in the present study were pre-chilling for 12 weeks, followed by germination at $25^{\circ} \mathrm{C}$, and normal seedling counts at 7 and 15 days. The progeny submitted to molecular marker sexing was composed of $61.3 \%$ female plants. The established methodologies presented here can be considered efficient and may contribute to expedite hops breeding programs.

Keywords: Breeding programs. Dioecious plants. Humulus lupulus
\end{abstract}

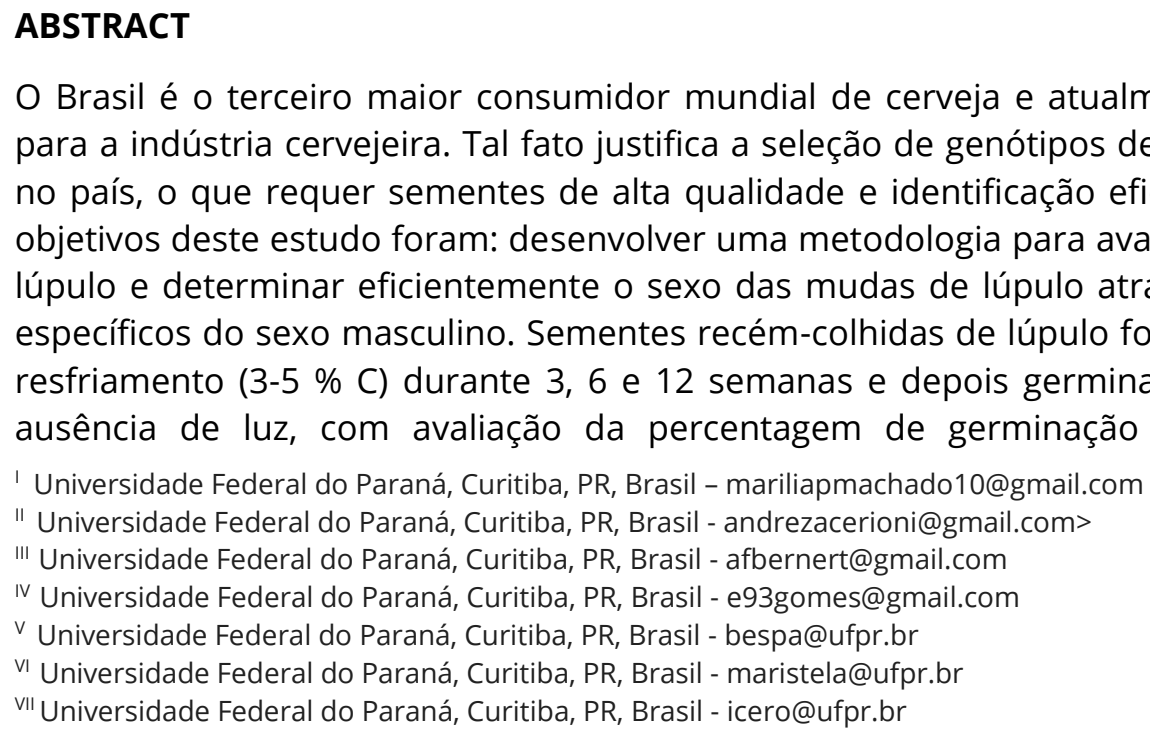

I Universidade Federal do Paraná, Curitiba, PR, Brasil - mariliapmachado10@gmail.com

" Universidade Federal do Paraná, Curitiba, PR, Brasil - andrezacerioni@gmail.com>

II' Universidade Federal do Paraná, Curitiba, PR, Brasil - afbernert@gmail.com

IV Universidade Federal do Paraná, Curitiba, PR, Brasil - e93gomes@gmail.com

$\checkmark$ Universidade Federal do Paraná, Curitiba, PR, Brasil - bespa@ufpr.br

VI Universidade Federal do Paraná, Curitiba, PR, Brasil - maristela@ufpr.br

VII Universidade Federal do Paraná, Curitiba, PR, Brasil - icero@ufpr.br

O Brasil é o terceiro maior consumidor mundial de cerveja e atualmente importa todo o seu lúpulo para a indústria cervejeira. Tal fato justifica a seleção de genótipos de lúpulo adaptados para o cultivo no país, o que requer sementes de alta qualidade e identificação eficiente do sexo das plântulas. Os objetivos deste estudo foram: desenvolver uma metodologia para avaliar a qualidade das sementes de lúpulo e determinar eficientemente o sexo das mudas de lúpulo através de marcadores moleculares específicos do sexo masculino. Sementes recém-colhidas de lúpulo foram germinadas com e sem préresfriamento $\left(3-5 \%\right.$ C) durante 3,6 e 12 semanas e depois germinadas a 20 e $25^{\circ} \mathrm{C}$ na presença e ausência de luz, com avaliação da percentagem de germinação e do índice de velocidade de 
germinação. Obtiveram-se progênies F1, a partir da germinação de sementes, em casa de vegetação e se identificou o sexo das seedlings por meio de marcadores moleculares macho-específicos. As melhores condições para a avaliação da qualidade fisiológica das sementes de lúpulo são o préresfriamento por 12 semanas, com germinação à $25^{\circ} \mathrm{C}$, e contagens de plântulas normais no $7^{\circ}$ e $15^{\circ}$ dias. A progênie submetida à sexagem por marcadores moleculares foi composta por $61,3 \%$ de plantas femininas. As metodologias estabelecidas aqui apresentadas podem ser consideradas eficientes e podem contribuir para acelerar os programas de melhoramento de lúpulo.

Keywords: Programas de melhoramento. Plantas dióicas. Humulus lupulus

\section{INTRODUCTION}

Humulus lupulus L., commonly known as the common hop, is a dioecious plant species belonging to the Cannabaceae family (DURAISAMY et al., 2016). Female plants are economically important due to the use of their flowers in the brewing industry (KARABÍN et al. 2016). The female inflorescences, also referred to as cones or strobiles, hold the lupulin glands, structures secreting secondary metabolites such as bitter acids and essential oils, which give the characteristic bitterness and aroma to beer (NANCE, SETZER, 2011; DURAISAMY et al. 2016; KARABÍN et al. 2016).

According to the International Hop Growers Convention (2019), hop cone production reached over 121,000 tons in 2019, with the USA and Germany as the main producers. Brazil imported over 2.7 thousand tons of hop cones in 2019 mostly in the form of pellets, with an estimated cost of US\$ 39 million (VENDEMIATTI, 2020). Such a dependency on imported raw materials, coupled with the growing market for craft beers, which, in some cases, are manufactured with fresh hops, increases the demand for locally grown hops, making it necessary to develop new genotypes, better adapted to Brazilian edaphoclimatic conditions.

Although hop plants are clonally propagated for commercial purposes (GOMES et al., 2018; MACHADO et al., 2018), sexual propagation is a fundamental feature of breeding programs and, therefore, the determination of seed quality and standardization of germination tests are strategic approaches for the efficient production of new cultivars.

Hop seeds are known to present low germination percentages due to dormancy (SUCIU et al., 1977; LIBERATORE et al., 2018), making it necessary to study 
specific treatments to promote germination as well as the elucidation of specific aspects of dormancy in the species. Several studies on the germination of hop seeds have been conducted (KELLER, 1953; SUCIU et al., 1977; LIBERATORE et al., 2018). In one of the most recent, a new protocol was developed for the In vitro germination of seeds using sulfuric acid for chemical scarification and gibberellic acid as a plant growth regulator to induce germination (LIBERATORE et al., 2018). In vitro techniques, however, usually require a specific infrastructure and relatively high investments. Thus, the study of more costly-effective methodologies is still necessary to improve hop breeding programs.

Morphologically, hop plants the difference between male and female can only be reliably distinguished after flowering, which can take up to 1-2 years after planting (PATZAK et al., 2002). Such a relatively long timespan can slow down breeding programs and the release of new cultivars, as only the female plants are of commercial interest.

With the advance of molecular biology techniques, breeding programs have been using marker-assisted selection for different traits (MAHARAJAN et al., 2018; Singh et al., 2018). Such methods can also be applied in the early stages of plant development, significantly reducing the time required to select female plants ( $\mathrm{XU}$, CROUCH, 2008). For hops, molecular marker-assisted selection was successfully applied to determine the sex of F1 progenies (PATZAK et al., 2002), highlighting the possibility of using this technology to expedite the selection of female plant during breeding programs.

Aiming to contribute with new information on hop plant propagation and breeding programs in Brazil, the objectives of the present work were to develop an efficient methodology for the assessment of hop seed quality and to determine the sex of hop seedlings via male-specific molecular markers. 


\section{MATERIALS AND METHODS}

\subsection{Plant material}

Branches with strobiles (cones) were collected in April of 2018 from 4 female hop accessions (identified as accessions 1, 2, 3 and 4) grown at an experimental area in the city of Pinhais, Brazil (25²3'12.3"S 4907'33.2"W, 895 meters ASL). Fertilization of female inflorescences was carried out by controlled pollination with pollen from the male cultivar Hallertau, grown in the same experimental area. The hops accessions were grown in a training system with $7 \mathrm{~m}$ height trellis wires from which two baling twines were stretched to ground level for each plant. The twines were attached to the ground using wooden stakes. Two twines were used for each plant, with two hop branches on each twine.

Strobiles were manually detached from the branches and the seeds were obtained by frictioning the strobiles against a set of three circular mesh sieves (diameters of 7.0; 5.0; and $2.0 \mathrm{~mm}$ ). Impurities such as bracts, bracteoles and floral racemes were discarded, and the seeds were homogenized according to the manual method described by the Brazilian Rules for Seed Analysis (BRASIL, 2009).

\subsection{Assessment of seed quality}

The assessments of seed quality were performed using seeds collected from accession 1 mother plant (F1 hybrids of accession 1 and Hallertau). Physical quality was assessed by the water content, using the low temperature oven method (101$105^{\circ} \mathrm{C}$ for 17 hours), and by the thousand-seed weight (TSW), according to the International Rules for Seed Testing (ISTA, 2015).

Freshly harvested hop seeds were submitted to pre-chilling treatments for physiological dormancy breaking. Seeds were soaked in a moistened paper towel (amount of water equivalent to 2.5 times the weight of dry substrate) and then placed in a polyethylene container and stored in a refrigerator $\left(3\right.$ to $5^{\circ} \mathrm{C}$ ) for periods of 3,6 and 12 weeks. The control treatment consisted of seeds not submitted to pre-chilling. 
After pre-chilling, seeds were sown on wet blotting paper (water at 2.5 times the weight of dry substrate weight) inside plastic boxes $(11.0 \times 11.0 \times 3.5 \mathrm{~cm})$, and, subsequently, placed in a Mangelsdorf $\AA$ germinator. Two temperatures $\left(20\right.$ and $25^{\circ} \mathrm{C}$ ) and two light regimes (with and without) were tested.

The physiological quality of the seeds was periodically assessed by normal seedlings counting until no further germination was observed. The definition of normal and abnormal seedlings was based on observation of images taken from a camera attached to a stereoscopic microscope. Normal seedlings were those with well-developed shoots and roots, intact or with small defects (ISTA, 2015). Results were expressed as percentage of normal seedlings. Germination speed index - GSI (MAGUIRE, 1962) and germination percentage were also determined.

The experiment was conducted in a completely randomized design in a $4 \times 2 \times 2$ three-level factorial scheme (pre-chilling time $x$ temperature $x$ light regime), with 4 repetitions, each one with 25 seeds. Data were submitted to analysis of variance (ANOVA) and where necessary the means were compared by the Tukey's test ( $p \leq$ $0.05)$

\section{3 owing and establishment of F1 progenies in greenhouse}

F1 seeds from crosses between the male cultivar Hallertau and accessions 1, 2, 3 and 4 were stored in glass containers and placed in a refrigerator $\left(3\right.$ to $5^{\circ} \mathrm{C}$ ) for 12 weeks. After pre-chilling, seeds were sown in expanded polystyrene trays (cell dimensions of $2.1 \times 2.1 \times 4.3 \mathrm{~cm}$ ) containing commercial substrate (Topstrato $®$ ). The trays were kept under intermittent misting (15 seconds misting every 30 minutes) throughout the period of the experiment. Seedlings emergence (\%) was evaluated 40 days after sowing.

The experiment was conducted in a completely randomized design with 4 treatments ( $F 1$ hybrids from each one of the 4 accessions with Hallertau), 5 replications, each one with 16 seeds. Boxplot analysis was performed in order to graphically compare the descriptive data of emergence percentage among the F1 hybrids. 


\subsection{Identification of sex in hop seedlings through male-specific markers}

Genomic DNA was extracted from 75 hop seedlings by the cetyl trimethylammonium bromide (CTAB) method (DOYLE, DOYLE, 1990). The third pair of leaves from 90-day hop seedlings was used as a source of the genetic material. The third pair of leaves from one male and one female adult plant were used as the positive and negative controls, respectively.

Polymerase chain reactions (PCR) were carried out in a total volume of $20 \mu \mathrm{L}$ with $1 \mu \mathrm{L}$ plant DNA, $2 \mu \mathrm{L}$ 10X buffer, $1.2 \mu \mathrm{L} \mathrm{MgCl} 2$ (950 mM), $2 \mu \mathrm{L}$ dNTPs (2mM), $30 \mathrm{ng}$ $\mu \mathrm{L}-1$ of each of the primers (STSF: 5'ACAGAGTACAACTCAGAAACAAACC 3', STSR: 5'AAGGTCGCACAATGACCG 3') (PATZAK et al., 2002), $0.1 \mu \mathrm{L}$ Taq polymerase (5U/u/L) and $13.3 \mu \mathrm{L}$ ultrapure $\mathrm{H} 2 \mathrm{O}$.

Amplification conditions were: an initial denaturation for 3 minutes at $94{ }^{\circ} \mathrm{C}$, followed by 35 cycles, each consisting of 30 seconds at $94{ }^{\circ} \mathrm{C}$ (denaturation step), followed by 60 seconds at $54{ }^{\circ} \mathrm{C}$ (annealing step) and an extension of 1.5 minutes at $72{ }^{\circ} \mathrm{C}$. The amplification was concluded by a final extension at $72{ }^{\circ} \mathrm{C}$ for 10 minutes.

PCR products were stained with GelRed ${ }^{\circledR}(3 \mu \mathrm{L})$ plus $6 \mathrm{X}$ TAE $(2 \mu \mathrm{L})$ and separated on an agarose gel (0.8 \%) using TBE buffer at 150V for two hours. The 100 bp ladder molecular weight marker was used (Ludwig Biotec ${ }^{\circledR}$ ).

\section{RESULTS AND DISCUSSION}

Humulus lupulus produces round-shaped dry fruits, characterized as achenes, with the seeds attached to the fruit wall. The fruits present a light brown pericarp (Figure 1C) when immature and dark brown when mature (Figure 1D). Translucent yellow lupulin from the bracts and bracteoles is present on the fruit surface (Figure 1E). The thousand-seed weight and water content of freshly harvested hop seeds from the accession $1 \times$ Hallertau F1 hybrids, was $4.64 \mathrm{~g}$ and 14.8\%, respectively. Maturation of hop fruits in the same infructescence was not uniform as observed by the differences in seed color during processing (Figure 1C-D). 
Figure 1 - Characterization of hop cones, seeds and seedlings. A: Freshly harvested hop cone; B: Longitudinal section of hop cone to expose the bracts and seed; C: Immature seed with light color; D: Mature seed with darker color; E-F: Internal hop seed morphology; G-I: Normal hop seedlings; J-L: Abnormal hop seedlings; co: cotyledons; hy: hypocotyl; rp: primary root.
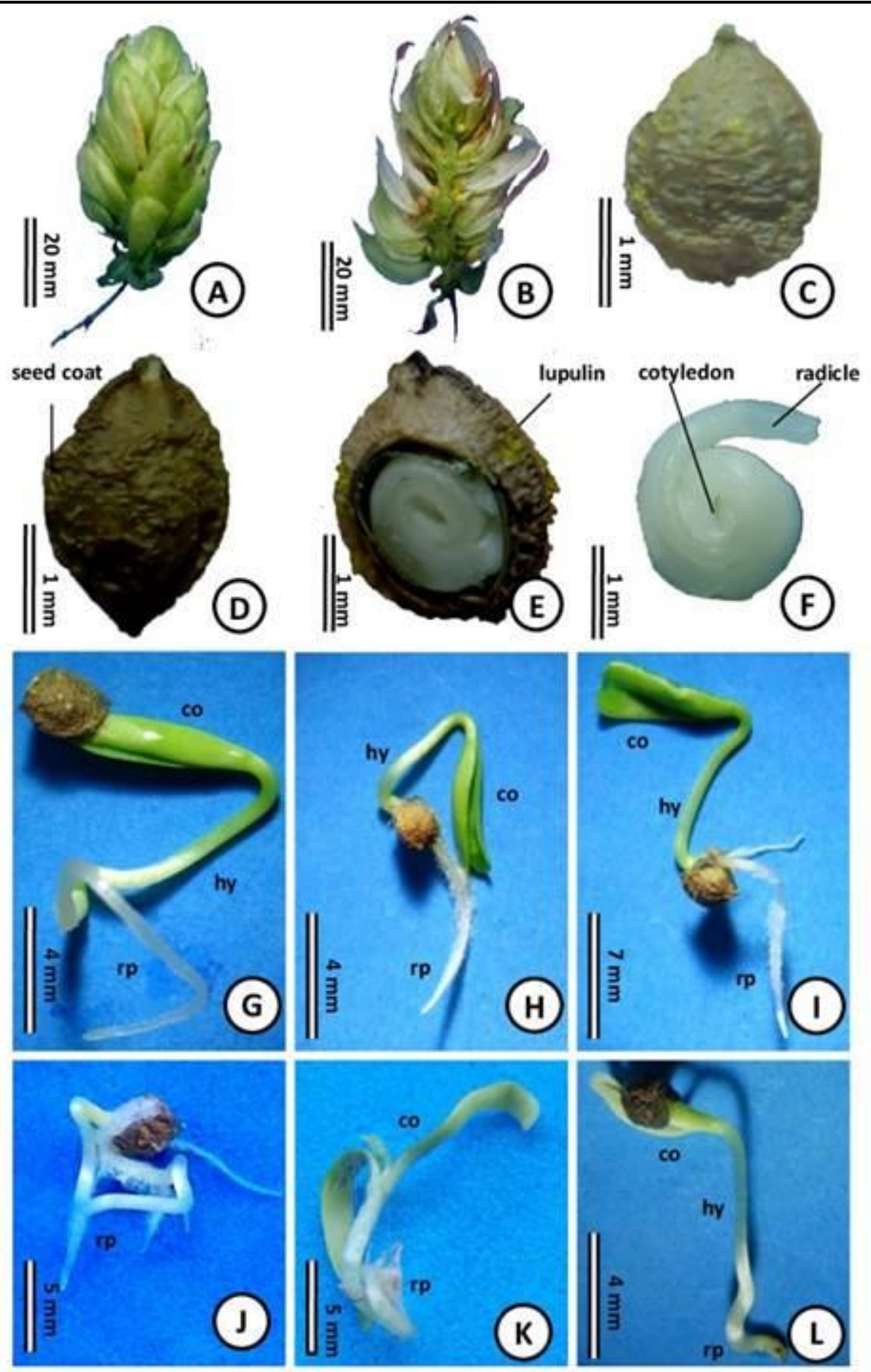
Lupulin adhered to the seed pericarp (Figure $1 \mathrm{E}$ ) is known to be composed of several secondary metabolites, such as soft and hard resins and essential oils, which may be involved in seed dormancy by preventing the absorption of water and oxygen (SUCIU et al., 1977). In the present study, only the dark brown seeds were used for the germination studies, using this visual pattern as an indicator of physiological maturity, as adopted for other species (KAISER et al., 2016).

For the assessment of seed germination, criteria for normal and abnormal seedlings were defined. Normal seedlings (Figure 1G-I) were those with healthy, welldeveloped, complete and proportionate essential structures (BRASIL, 2009). The shoots were composed of cylindrical hypocotyl (hy) and intact, light green expanded cotyledons (co), while the root system consisted of cylindrical primary root (rp) with a thinner distal end, indicating the root cap. Seedlings abnormalities (Figure 1J-L) were generally related to root system malformation (Figure $1 \mathrm{~K}$ ) and root cap necrosis (Figure 1L).

Hop seed germination was influenced by the treatments, with significant interaction among the studied factors (Table 1). The highest germination percentages were obtained when the seeds remained for 12 weeks under pre-chilling (84 to 89\%), regardless of temperature and light regime. Shorter periods of cold exposure promoted low germination percentages (up to $20 \%$ for 6 weeks pre-chilling at $25^{\circ} \mathrm{C}$ with light) and no germination was observed in the control treatment (no pre-chilling). With respect to the germination speed, the GSI was also higher when seeds were treated with pre-chilling for 12 weeks, regardless of temperature and light regime (Table 1). 
Table 1 - Germination percentage and germination speed index of hop seeds under different pre-chilling periods at 3-5 ${ }^{\circ} \mathrm{C}$, germination temperatures and light regimes.

\begin{tabular}{l|c|c|c|c}
\hline \multirow{2}{*}{$\begin{array}{c}\text { Pre-chilling } \\
\text { (number of weeks) }\end{array}$} & \multicolumn{4}{|c}{ Germination (\%) } \\
\cline { 2 - 5 } & \multicolumn{2}{|c|}{$\mathbf{2 0}^{\circ} \mathbf{C}$} & \multicolumn{2}{c}{$\mathbf{2 5}{ }^{\circ} \mathbf{C}$} \\
\cline { 2 - 5 } & Light & Dark & Light & Dark \\
\hline 0 & $1 \mathrm{bA}$ & $\mathrm{CA}$ & $2 \mathrm{cA}$ & $9 \mathrm{cA}$ \\
\hline 3 & $4 \mathrm{bB}$ & $04 \mathrm{bcB}$ & $0 \mathrm{cB}$ & $11 \mathrm{cA}$ \\
\hline 6 & $12 \mathrm{bA}$ & $14 \mathrm{bA}$ & $20 \mathrm{bA}$ & $87 \mathrm{aA}$ \\
\hline 12 & $84 \mathrm{aA}$ & $89 \mathrm{aA}$ & $87 \mathrm{aA}$ & \\
\hline $\mathrm{CV}(\%)$ & \multicolumn{4}{|c}{} \\
\hline
\end{tabular}

\section{Pre-chilling}

(number of weeks)

\begin{tabular}{l|l|l|l|l}
\hline 0 & $0.005 \mathrm{bA}$ & $0.000 \mathrm{bA}$ & $0.011 \mathrm{bA}$ & $0.077 \mathrm{cA}$ \\
\hline 3 & $0.055 \mathrm{bB}$ & $0.060 \mathrm{bB}$ & $0.000 \mathrm{bB}$ & $0.768 \mathrm{bA}$ \\
\hline 6 & $0.281 \mathrm{bA}$ & $0.310 \mathrm{bA}$ & $0.446 \mathrm{bA}$ & $0.273 \mathrm{bcA}$ \\
\hline 12 & $3.311 \mathrm{aA}$ & $3.476 \mathrm{aA}$ & $3.790 \mathrm{aA}$ & $3.410 \mathrm{aA}$ \\
\hline $\mathrm{CV}(\%)$ & \multicolumn{3}{|l}{28.11}
\end{tabular}

Means followed by the same uppercase letter in the rows and lowercase letter in the columns do not differ significantly according to the Tukey test $(p \leq 0.05)$.

The significant increase in germination percentage of freshly harvested hop seeds after pre-chilling (Table 1) may be related to dormancy breaking by stimulating gibberellin biosynthesis (BENTSINK, KOORNNEEF, 2008). However, further studies are still needed to elucidate the cause of this phenomenon in this species, and in different genotypes, seeking alternatives to expedite the germination process.

The need for 12 weeks of pre-chilling for hop seed germination is probably related to the plant's ecophysiology in its place of origin, regions with a temperate climate. Although hop plants are perennial, their shoots undergo senescence and their rhizomes remain dormant until a certain number of chill hours are accumulated, varying in accordance with the genotype .It is well known in the scientific literature that the degree of dormancy in several plant species is closely related to the climatic conditions encountered in the region from which those species originate (NEWTON et al., 2015).

The results concerning the light regimes (Table 1) show that hop seeds are neutral photoblastic, meaning that no artificial light is necessary to conduct the germination experiments, which makes it easier and less expensive to conduct research on this species. 
Figure 2 shows the mean germination percentages of seeds (normal seedlings) submitted to 12 weeks pre-chilling at different evaluation times and with different temperatures and light regimes. The germination peak occurred between 5 and 7 days after sowing (Figure 2) and no germination was observed after 15 days. Thus, germination trials for hops may be conducted with the first germination assessment at 7 days and last evaluation at 15 days after sowing. The temperature of $25{ }^{\circ} \mathrm{C}$ in combination with the absence of light showed slightly better results across time, therefore such a combination could be recommended for future studies. Studies on hop seed germination are scarce (KELLER, 1953; SUCIU et al., 1977) and the definition of a standard methodology to evaluate the physiological quality of the seeds has not been investigated so far.

Figure 2 - Daily germination percentage of pre-chilled hop seeds under different temperature and light conditions over a 15-week period. $n=4$. C.V. $=5.3 \%$

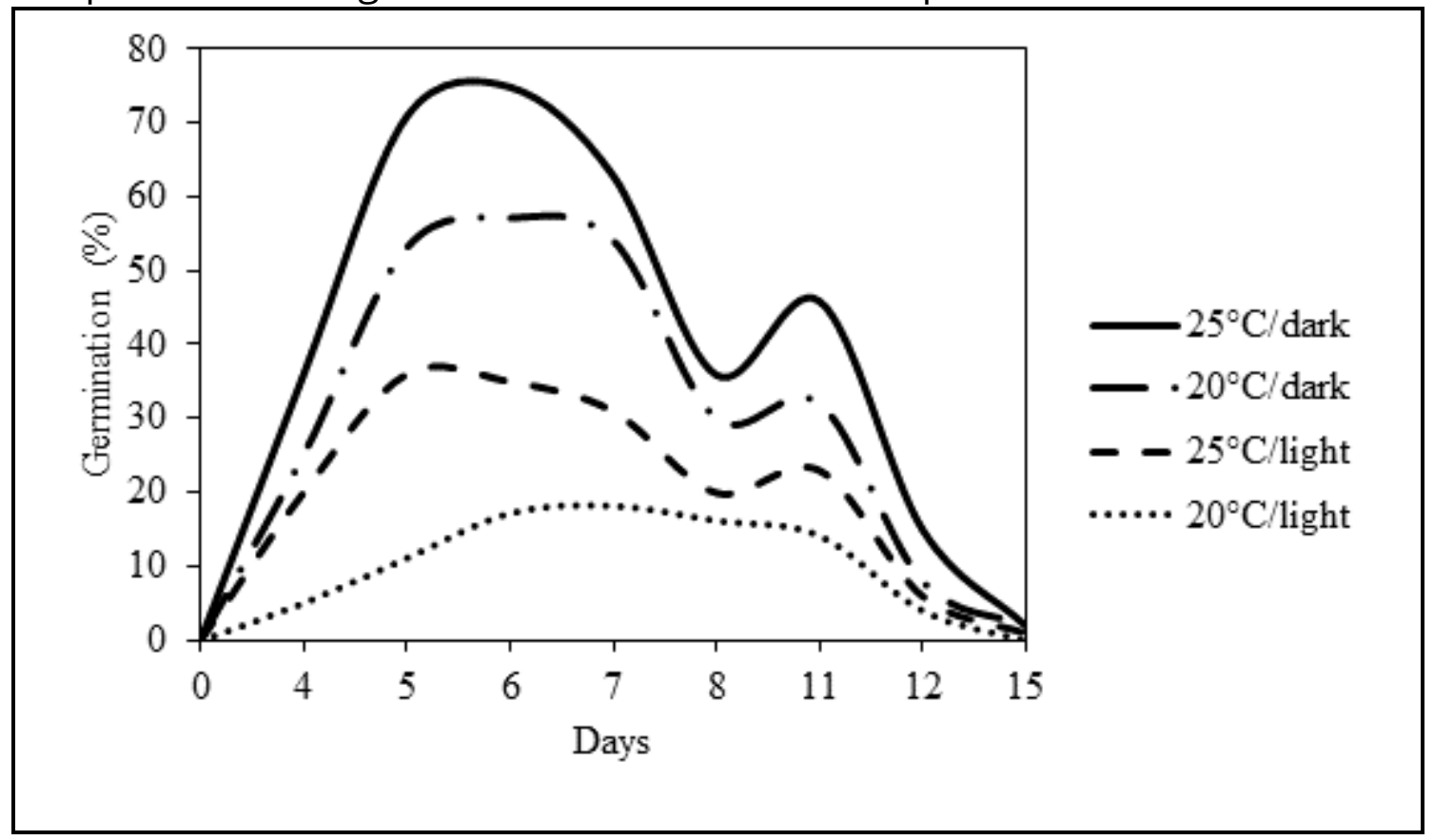

Mean germination percentage of the F1 hybrids varied from $20 \%$ to $43 \%$, according to the mother plant (accessions 1, 2, 3 and 4). Seed germination varied from $29 \%$ to $56 \%$ in the accession $1 \times$ Hallertau hybrids, while seeds coming from accession $2 \times$ Hallertau cross presented the highest germination mean (43\%). Seeds from accession $3 \times$ Hallertau showed low variation in the germination percentage, 25 to 
$35 \%$ in $50 \%$ of the sample, with maximum germination of $36 \%$. The lowest germination percentage was observed for accession $4 \times$ Hallertau hybrids (17\%) (Figure 3).

Figure 3 - Boxplot analysis of the variability in seed germination (\%) among individual plants of four hop accessions. Whiskers represent the extreme range of values.

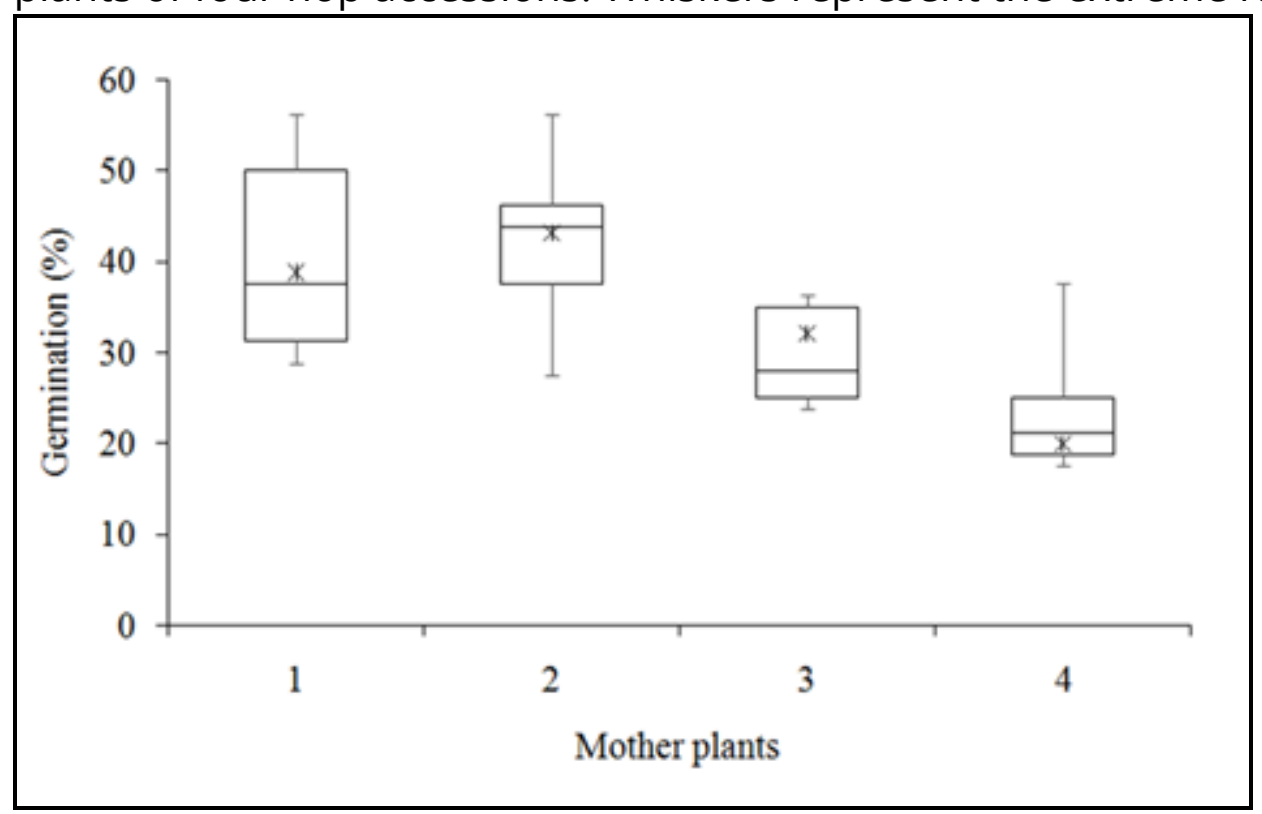

*The top and bottom of each box is the 75th and 25th percentile, respectively. Lines represent the median and asterisks represent means.

The variation in germination percentage for different progenies could be of genetic origin or motivated by the environmental conditions to which the mother plants are subjected during seed maturation, which can affect dormancy level, as observed in Arabidopsis thaliana (HE et al., 2014). The variation can also be understood as an adaptive strategy to prevent all seeds from germinating simultaneously, avoiding the risk of progeny-wide mortality (SIMONS, JOHNSTON, 2006).

The maximum germination percentage observed when seeds were sown on trays under greenhouse conditions in the present experiment (56\%) was similar to those reported for in vitro germinated hop seeds cv. Columbus, with gibberellin treatment (LIBERATORE et al., 2018). As the germination tests showed that the potential hop seed germination is higher ( $89 \%$ seed germination after prechilling) than those observed under greenhouse conditions, further studies are needed to establish 
more efficient dormancy breaking methods and the ideal conditions for hop germination and emergence in the field and under greenhouse conditions.

After 40 days under greenhouse conditions, seedlings were at different stages of development due to differences in the speed of seed germination. All seedlings that survived the germination process, when they reached the three pairs of leaves stage, were transferred to pots and kept under greenhouse conditions.

Seedlings analyzed by molecular markers were identified by the presence or absence of a specific band. Seedlings with an amplified band were identified as male, while the absence of the band characterized female seedlings. Positive and negative controls consisted of the same amplification reaction carried out on DNA samples form adult male and female plants, respectively (Figure 4). From the 75 seedlings analyzed in this study, $61.3 \%$ were identified as female and $38.7 \%$ identified as male.

Figure 4 - Amplification pattern of hop genotypes. Arrow: control male-specific PCR marker; M: 100 bp Ladder

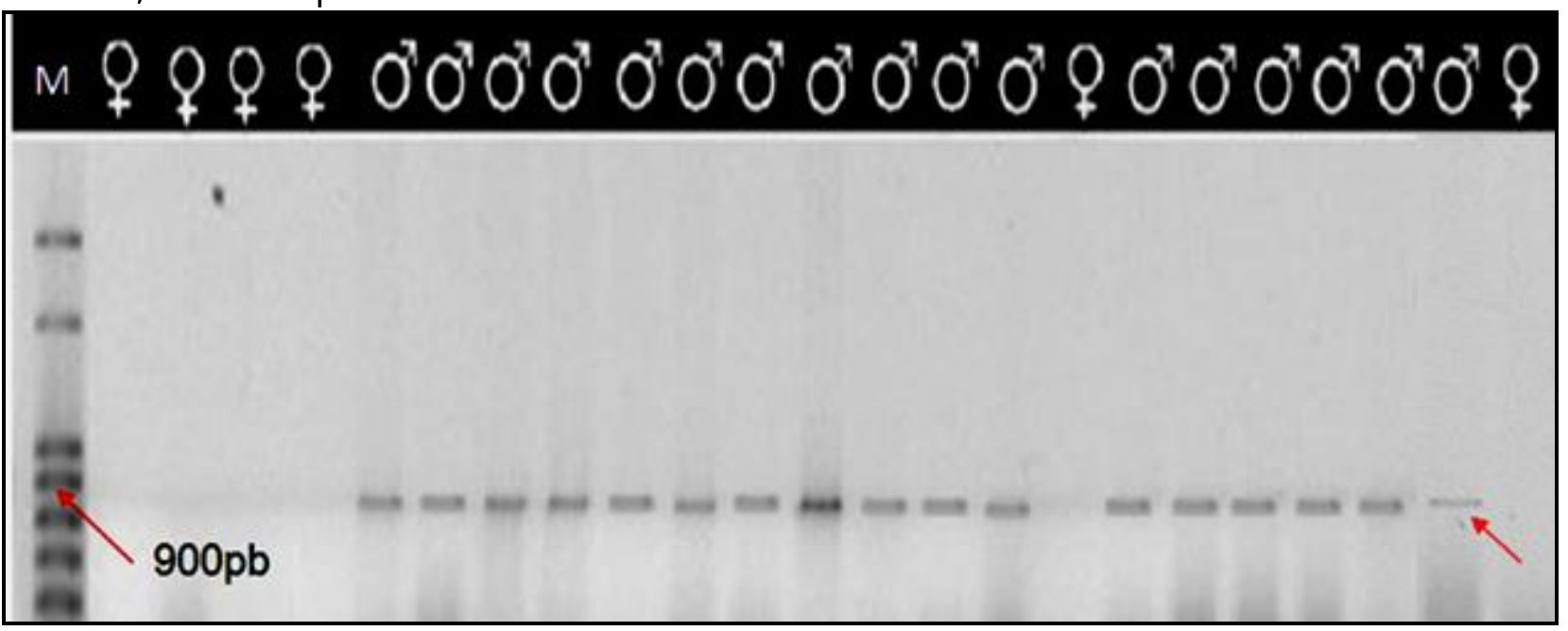

Different PCR techniques have been reported for sex determination in hop seedlings, such as inter simple sequence repeat (ISSR-PCR) (DANILOV, KARLOV, 2006) and amplified fragment length polymorphism (AFLP-PCR) (Seefelder et al 2008). In addition, random amplified polymorphic DNA (RAPD) and ISSR primers were also used for sex determination in Japanese hops (Humulus japonicus Siebold \& Zucc.) (ALEKSANDROV et al., 2011). 
The molecular markers used in the present study were previously considered to be highly efficient for sex determination of a group of 840 hop seedlings (PATZAK et al. 2002). The female to male ratio found in the present study is similar to results published on cv. Columbus hop seedlings, using sex-linked molecular markers (LIBERATORE et al., 2018).

Sex determination in hop seedlings via molecular markers is a strategic approach, as it can promote optimization of breeding programs (SAKIYAMA et al., 2014), considering that only unfertilized inflorescences of female plants are economically important. The female plants identified in the present study will be further used in breeding programs aiming to select genotypes that are better adapted to the Brazilian conditions of growth.

\section{RESULTS AND DISCUSSION}

New information on hop plants propagation is provided. An efficient methodology for assessment of physiological quality of hop seeds can be performed with pre-chilling for 12 weeks, followed by germinator conditions at $25^{\circ} \mathrm{C}$ and no light. Germination counts can be started at 7 days and end at 15 days after sowing. The germination of seeds from the crosses between the male cultivar Hallertau and different female accessions does not occur homogenously. Further studies are required to investigate the causes of such variation in order to improve propagation in breeding programs.

Sex determination in hop seedlings by male-specific molecular markers is efficient for the F1 hybrids assessed in the present study and can be used to improve breeding programs.

\section{REFERENCES}

ALEKSANDROV, O. S.; DIVASHUK, M. G.; KARLOV, G. I. Development of a Sex Specific Molecular Marker for Japanese Hop Humulus Japonicus Siebold \& Zucc. Russian Journal of Genetics, Springer Nature Switzerland, v.47, p.1016-1020, Aug. 2011. Available from: https://doi.org/10.1134/S1022795411080023. Accessed: Mar. 22, 2019. 
BENTSINK, L.; KOORNNEEF, M. Seed dormancy and germination. The Arabidopsis book. v.6, p.1-18, Dec. 2008. Available from: https://doi.org/10.1199/tab.0119. Accessed: Jan. 12, 2019.

BRASIL. Ministério da Agricultura, Pecuária e Abastecimento. Regras para Análise de Sementes. Brasília, 2009, $395 \quad$ p. Available from: http://www.agricultura.gov.br/assuntos/insumos-agropecuarios/arquivos-publicacoesinsumos/2946_regras_analise_sementes.pdf.

DANILOVA, T. V.; KARLOV, G. I. Application of inter simple sequence repeat (ISSR) polymorphism for detection of sex-specific molecular markers in hop (Humulus lupulus L.). Euphytica, v.151, p.15-21, Oct. 2006. Available from: https://doi.org/10.1007/s10681-005-9020-4. Accessed: Apr. 12, 2019.

DOYLE, J. J.; DOYLE, J. L. Isolation of plant DNA from fresh tissue. Focus, v.12, p.13-15, 1990. Available from: https://ci.nii.ac.jp/naid/10003365693/. Accessed: Feb. 17, 2019.

DURAISAMY, G. S.; MISHRA, A. K.; KOCABEK, T.; MATOUŠEK, J. Identification and characterization of promoters and cis-regulatory elements of genes involved in secondary metabolites production in hop (Humulus lupulus L). Computational Biology and Chemistry, v.64, p.346-352, Feb. 2019Available from: https://doi.org/10.1016/j.compbiolchem.2016.07.010. Accessed: Feb. 2019.

GOMES, E. M.; MACHADO, M. P.; MIOLA, J.; DESCHAMPS, C. Leaf area and intermittent misting on hop plants propagation by stem cuttings. Revista Colombiana de Ciencias Horticolas, v.12, p.508-513, May. 2018. Available from: https://doi.org/10.17584/rcch.2018v12i2.7652.

HE, H.; VIDIGAL, D. S.; SNOEK, L. B.; SCHABEL, S.; NIJVEEN, H.; HILHORST, H.; BENTSINK, L. Interaction between parental environment and genotype affects plant and seed performance in Arabidopsis. Journal of Experimental Botany, v.65, p.6603-6615, Dec. 2014. Available from: https://doi.org/10.1093/jxb/eru378.

INTERNATIONAL SEED TESTING ASSOCIATION (ISTA) International Rules for Seed Testing. ISTA. Bassersdorf, SW, 2015.

INTERNATIONAL HOP GROWERS CONVENTION (IHCG). Economic committee, 2018. Available from: http://www.hmelj-giz.si/ihgc/obj.htm. Accessed: October 1, 2018.

KAISER, D. K.; MALAVASI, M. M.; MALAVASI, U. C.; DRANSKI, J. A. L.; FREITAS, L.C.N.; KOSMAN, C.R.; ANDRIOLI, K.K. Physiological maturity of seeds and colorimetry of the fruits of Allophylus edulis [(A.St.-Hil., A. Juss. \& Cambess.) Hieron. Ex Niederl.]. Journal of Seed Science, Abrates Londrina, v.38, p.92-100, Jun. 2016. Available from: https://doi.org/10.1590/23171545v38n2154590. Accessed: Mai. 2, 2019.

KARABÍN, M.; HUDCOVÁ, T.; JELÍNEK, L.; DOSTÁLEK, P. Biologically active compounds from hops and prospects for their use. Comprehensive Reviews in Food Science and Food Safety, Wiley Online Library, v.15, p.542-567, Mar. 2016. Available from: https://doi.org/10.1111/1541-4337.12201 Accessed Mai. 8, 2019. 
KELLER, K. R. Seed germination in hop, Humulus lupulus L. Agronomy Journal, Wiley Online Library, v.45, p.146-150, Mar. $1953 . \quad$ Available from: https://dl.sciencesocieties.org/publications/aj/abstracts/45/4/AJ0450040146?access=0\&v iew=pdf Accessed Mai. 2, 2019.

LIBERATORE, C. M.; MATTION, G.; RODOLFI, M.; GANINO, A.; FABBRI, A.; CHIANCONEA, B. Chemical and physical pre-treatments to improve in vitro seed germination of Humulus Iupulus L., cv. Columbus. Scientia Horticulturae, Elsevier, v.235, p.86-94, May. 2018. Available from: https://doi.org/10.1016/j.scienta.2018.02.077 Accessed Apr. 12, 2019.

MACHADO, M. P.; GOMES, E. N.; FRANCISCO, F.; BERNERT, A. F.; BESPALHOK-FILHO, J. C.; DESCHAMPS, C. Micropropagation and Establishment of Humulus lupulus L. Plantlets Under Field Conditions at Southern Brazil. Journal of Agricultural Science, The Canadian Center of Science and Education, v.10, p.275-281, Jun. 2018. Available from: https://doi.org/10.5539/jas.v10n7p275 Accessed Jan. 12, 2019.

MAGUIRE, J. D. Speed of germination - aid in selection and evolution for seedling emergence and vigor. Crop Science, Wiley Online Library, v.2, p.176-177, Mar. 1962. Available from: https://doi.org/10.2135/cropsci1962.0011183X000200020033x Accessed Apr. 26, 2019.

MAHARAJAN, T.; CEASAR, S. A.; KRISHNA, T. P. A.; RAMAKRISHNAN, M.; DURAIPANDIYAN, V.; ABDULLA, I. S. Utilization of molecular markers for improving the phosphorus efficiency in crop plants. Plant Breeding, Wiley Online Library, v.137, p.10-26, Oct. 2018. Available from: https://doi.org/10.1111/pbr.12537 Accessed Apr. 7, 2019.

NANCE, M. R.; SETZER, W. N. Volatile components of aroma hops (Humulus lupulus L.) commonly used in beer brewing. Journal of Brewing and Distilling, Academic Journals, v.2, p.16-22, Apr. 2011. Available from: https://academicjournals.org/journal/JBD/article-full-textpdf/4027AE2252 Accessed Apr. 22, 2019.

NEWTON, R. J.; HAY, F. R.; ELLIS, R. H. Ecophysiology of seed dormancy and the control of germination in early spring flowering Galanthus nivalis and Narcissus pseudonarcissus (Amaryllidaceae). Botanical Journal of the Linnean Society, Oxford academic, v.177, p. 246-262, Feb. 2015. Available from: https://doi.org/10.1111/boj.12240 Accessed Apr. 7, 2019.

PATZAK, J.; VEJL, P.; SKUPINOVA, S.; NEWADBA, V. Identification of sex in F1 progenies of hop (Humulus lupulus L.). Rostlinna Vyroba, CAAS Agriculture journals, v.48, p.318-321, 2002. Available from: https://doi.org/10.17221/4367-PSE Accessed January 20, 2019.

SAKIYAMA, N. S.; RAMOS, H. C. C.; CAIXETA, E. T. P. Plant breeding with marker-assisted selection in Brazil. Crop Breeding and Applied Biotecnology, Viçosa, v.14, p. 54-60, Mar. 2014. Available from: https://doi.org/10.1590/\$1984-70332014000100009 Accessed January 10, 2019.

SEEFELDER, S.; EHRMAIER, H.; SCHWEIZER, G.; SEIGNER, E. Male and female genetic linkage map of hops, Humulus Iupulus. Plant Breeding, Wiley Online Library, v.119, p.249-245, Jun. 2008. Available from: https://doi.org/10.1046/j.1439-0523.2000.00469.x Accessed March 10, 2019. 
SIMONS, A. M.; JOHNSTON, M. O. Environmental and genetics sources of diversification in the timing of seed germination: implications for the evolution of bet hedging. Evolution, v.60, p.2280-2292, 2006. Available from: https://doi.org/10.1554/05-396.1 Accessed March 25, 2019.

SINGH, S.; DEY, S. S.; BHATIA, R.; BATLEY, J.; KUMAR, R. Molecular breeding for resistance to black rot [Xanthomonas campestris pv. campestris (Pammel) Dowson] in Brassicas: recent advances. Euphytica, Springer Nature Switzerland, v.214, p.1-17, Oct. 2018. Available from: https://doi.org/10.1007/s10681-018-2275-3 Accessed March 4, 2019.

SUCIU, T.; SALONTAI, A.; MUNTEAN, L.; FELECAN, V.; VAIDA, L. Recherches concernant la germination des semences de houblon. Notulae Botanicae Horti Agrobotanici, v.9, p.79-84, 1977.

VASCONCELOS, Y. Inovações cervejeiras. Pesquisa FAPESP, v.251, p.18-25, 2017.

VENDEMIATTI, A. Beer Marketing Report, USDA. 2020. Available from: http://usdabrazil.org.br/pt-br/reports/beer-market-report-2019.pdf Accessed Jun. 1, 2020.

$\mathrm{XU}, \mathrm{Y}$; $\mathrm{CROUCH}, \mathrm{J} . \mathrm{H}$. Marker-assisted selection in plant breeding: from publication to practice. Crop Science, Wiley Online Library, v.48, p.391-407, Mar. 2008. Available from: https://doi.org/10.2135/cropsci2007.04.0191 Accessed Apr. 14, 2019. 